\title{
Determinants of E-Commerce in Indian MSME Sector: A Conceptual Research Model Based on TOE Framework
}

\author{
Girish S. Bagale \\ SBM, SVKM's NMIMS University, Mumbai-56, India \\ *Corresponding Author: girish.bagale@nmims.edu
}

Copyright (C) 2014 Horizon Research Publishing All rights reserved.

\begin{abstract}
This paper proposes research framework to study impact of organizational factors on E-Commerce Implementation in Indian MSME sector. It also shows the profound impact of MSME sector on Indian Economy, status of E-commerce in India \& imperative of E-Commerce for Indian MSME sector. A literature review in this area.
\end{abstract}

Keywords E-Commerce, Micro, Small and Medium Enterprises (MSME) sector, EDI

\section{Introduction}

It is well-known that Micro, Small and Medium Enterprises (MSME) sector provides maximum opportunities for both self employment and jobs. In the era of globalization \& liberalization; SMEs are facing cut throat competition at local, national, international level. To keep their position intact $\&$ sustained in a long run; in this highly competitive market they need to implement new change \& technologies. E-Commerce (EC) is one of them. EC is affecting every aspect of every businesses of every country. SMEs to keep their competitive edge over others need to implement EC in their day to day work; otherwise their sustainability is a big question mark.

The use of e-commerce by SMEs may take many forms, from online purchasing of products, contacting suppliers through email, to marketing and selling their products through their own websites to international clients, which can be divided into upstream (business to business or B2B) and downstream (business to customer or B2C) activities. Upstream activities such as inbound logistics and operations can be organized globally to achieve economies of scale. Downstream activities such as marketing, sales and customer service must be organized on a multi-domestic basis. Most MSMEs use the internet for a very limited range of purposes, e.g. e-mail, an easier and more economic way to contact suppliers or receive services, as another medium for collecting information.

In an increasingly competitive and globalised world, Micro, Small \& Medium Enterprises (MSMEs) need to compete more effectively to boost domestic economic activities and contribute toward increasing export earnings. The E-commerce can help small enterprises to present themselves to the world. E-Commerce is emerging as a new way of helping business enterprises to compete in the marketplace and thereby contributing to their economic success. Micro, Small and Medium Enterprises (MSMEs) with a relatively small investments, profits can generate good business opportunities by automating their processes using electronic means. E-Commerce platforms like B2B Portal and B2C Portals are playing very good role in enhancing the reach of MSMEs globally.

MSMEs are increasingly seeing the benefits arising from e-commerce as expanded geographical coverage giving them a larger potential market into which they can sell their products and services. Akkeren and Cavaye [1] state that e-commerce improves an SME's ability to compete with larger organizations and operate on a global scale. They additionally see e-commerce as a tool for providing very effective ways in which for SME's to plug their business, launch new product, improve communications, gathering data and establishing potential business partners. The web permits small businesses to enter the domain of larger business and compete with them. Moreover, the utilization of e-commerce permits small businesses to attain equivalent efficiencies as large businesses.

\section{Significance of MSME Sector in India}

The definition of SMEs varies in different countries and studies. The term SME covers a wide range of definitions and measures, varying from country to country and varying between the sources reporting SME statistics [2].There is no single and fixed definition for small and medium companies and existing definitions is changed from country to country and from one industrial sector to other industrial sectors. SMEs are defined on the basis of number of employees employed \& investment; in most of the countries.

In India; Enterprises have been classified broadly into two categories, namely enterprises engaged in the manufacture/production of goods pertaining to any industry; 
\& enterprises engaged in providing/rendering of services. As per "Micro, Small and Medium Enterprises Development (MSMED) Act, 2006 of Govt. of India" [3]; MSMEs are defined in India as follows

Table 1. Definitions of SME after 2 October 2006[3]

\begin{tabular}{|c|c|c|}
\hline Classification & $\begin{array}{c}\text { Manufacturing } \\
\text { Enterprises* }\end{array}$ & Service Enterprises** \\
\hline Micro & $\begin{array}{c}\text { Up to Rs. } 2.5 \text { million } \\
\text { (US\$ } 50,000)\end{array}$ & $\begin{array}{c}\text { Up to Rs. 1 million } \\
\text { (US\$ 20,000) }\end{array}$ \\
\hline Small & $\begin{array}{c}\text { Rs. } 2.5 \text { to Rs. } 50 \text { million } \\
/ \text { (US\$ } 1 \text { million) }\end{array}$ & $\begin{array}{c}\text { Rs } 1 \text { to } 20 \text { million Rs } \\
\text { (US\$ 40,00,000) }\end{array}$ \\
\hline \multirow{2}{*}{ Medium } & $\begin{array}{c}\text { Rs.50 million to Rs.100 } \\
\text { million (US\$2 million) }\end{array}$ & $\begin{array}{c}\text { Rs } 20 \text { to } 50 \text { million } \\
\text { Rs (US\$ } 1 \text { million) }\end{array}$ \\
\hline
\end{tabular}

Investment ceiling for plant, machinery or equipments (excluding land \& building).

* Investment limit in Plant \& Machinery

** Investment limit in equipments ***Rs50 $=1 \mathrm{USD}$

\subsection{Contribution of MSME Sector to Indian Economy}

MSMEs, credited with generating the highest rate of employment after agriculture, account for a major share in industrial production and exports. This sector accounts for around $45 \%$ of the total manufacturing output; $40 \%$ of India's total exports and contributes around $8 \%$ in India's Gross Domestic Product (GDP). It employs about 59 million persons in over 26 million units across the country. There are over 6000 products ranging from traditional to high-tech items, which are being manufactured by the MSMEs in India. The total number of MSMEs operating in India significantly increased 207\% per cent between 2000-01 and 2009-10 and the sector registered a sterling $21.52 \%$ compounded annual growth in terms of production. The employment generating potential of the sector has also grown at an annual compounded rate of $11.74 \%$ in the last decade. Nearly $50 \%$ of the MSMEs are owned by disadvantaged groups of society. [4]

Table 2. Contribution of MSME sector to the total Industrial Production \& GDP of India.[4]

\begin{tabular}{|c|c|c|}
\hline \multirow{2}{*}{ Year } & \multicolumn{2}{|c|}{ Contribution of MSME(\%) to } \\
\cline { 2 - 3 } & $\begin{array}{c}\text { Total Industrial } \\
\text { Production }\end{array}$ & $\begin{array}{c}\text { Gross Domestic } \\
\text { Product(GDP) }\end{array}$ \\
\hline $2004-05$ & 38.62 & 5.84 \\
\hline $2005-06$ & 38.56 & 5.83 \\
\hline $2006-07$ & 45.62 & 7.20 \\
\hline $2007-08$ & 45.24 & 8.00 \\
\hline $2008-09$ & 44.86 & 8.72 \\
\hline
\end{tabular}

Manufacturing sector contributes around $15 \%$ in India's Gross Domestic Product (GDP). In that MSME sector contributes $8 \%$ in India's Gross Domestic Product (GDP) \& $45 \%$ of the total manufacturing output of India.

The below Graph describes the composition of the MSME in India. In the sector as a whole, majorities of enterprises are in the manufacturing space $(67 \%)$.

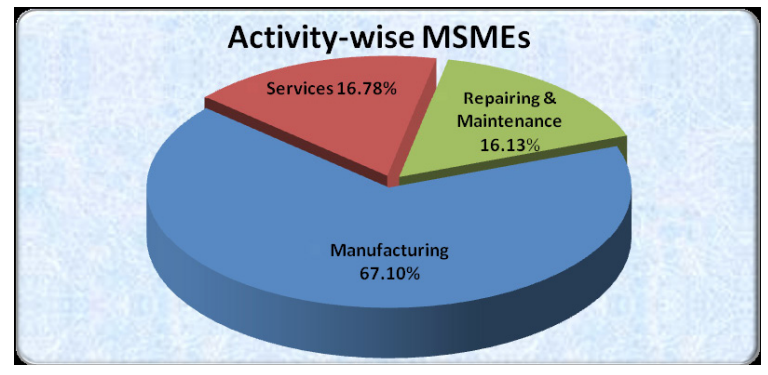

Graph 1. Describes the composition of the MSME in India. [4]

In the National Manufacturing Competitiveness Program (NMCP), MSMEs are under 'priority sector'. The share of manufacturing in India's GDP has stagnated at $15-16 \%$ since 1980 while the share in comparable economies in Asia is much higher at 25 to $34 \%$. [5]

National Manufacturing Policy envisages increasing the share of Manufacturing in GDP to $25 \%$ over the next decade and generating additional 100 million jobs in manufacturing sector through an annual average growth rate of $12-14 \%$ in manufacturing sector. MSME sector being the major base of manufacturing sector in India. This would call for quantum jump in plan allocation for the sector during the 12th Plan to address major bottlenecks facing the sector. [6]

Research suggests that SMEs are the major providers of new jobs and contribute positively to economic growth. SMEs make a significant contribution to India's economy. This important sector plays a vital role within the development of economy's infrastructure by providing employment generation, innovation and wealth creation. MSME sector contributes not only to higher rate of economic growth but also in building an inclusive and sustainable society in innumerable ways through creation of non-farm livelihood at low cost, balanced regional development, gender \& social balance, environmentally sustainable development and to top it all, recession proofing of economic growth, which the sector has proven time and again. SMEs are significantly contributing to industrial, economic, technological and regional developments in all economies, developed and developing.[7]

To make the sector significant player in the global market place, Government has taken a number of policy initiatives during the recent period. To identify issues inhabiting growth of the sector a task force was constituted by the prime minister in 2009. In its report; the task force made 85 recommendations to unshackle the Indian MSMEs.

Planning commission constituted the working group on micro small medium enterprises (MSMEs) Growth for the $12^{\text {th }}$ five year plan (2012-17) under the chairmanship of secretary (MSME) with 46 members representing various Ministries /offices of government of India, representatives of selected state governments and industry associations, NGOs etc in May, 2011.

\subsection{Schemes and Programs of the GOI for the Sustainable Growth of the MSME Sector}


To promote and support MSMEs, GOI are taking various initiatives along with running schemes and programs on following areas

1. Credit \& Finance

2. Competitive Technology

3. National Manufacturing Competitiveness Program (NMCP)

4. Skill Development

5. Marketing and Procurement

6. Export Promotion

7. Infrastructure Development

8. Fiscal Concessions

9. Micro, Small and Medium Enterprises Development Act, 2006

In some countries such as Singapore and Taiwan; the SMEs are base of economy. While in countries like Japan and Korea base of economy are big companies and small companies operate as their support. Globalization and India's robust economic growth have opened up several latent business opportunities for this sector. With all these developments, there is a huge scope for MSMEs to enter in international markets, explore opportunities abroad and make the 'Made in India' tag global. India has registered a high economic growth (6-9\%) consistently over the last one decade. For the sustainability of this kind of growth proper nurturing of MSME sector is imperative. The need of the hour is to empower the MSME Sector so that it is able to take its rightful place as the growth engine of the economy.

\section{E-Commerce in India}

Electronic commerce (EC) or e-commerce implies doing business activities for products and services \& other tasks electronically rather than by physical exchanges or direct physical contact. It is an Internet, Information \& Technology-based process. A more complete definition is: E-commerce is the use of electronic communications and digital information processing technology in business transactions to create, transform, and redefine relationships for value creation between or among organizations, and between organizations and individuals.

Kalakota and Whinston[8] defined EC on four perspectives. These four perspectives are:( see table3)

E-commerce not only permits but facilitates an increase in productivity enabling the creation of new relationships with customers, distributors, suppliers and other strategic partners. Schmid [9] details the benefit of Electronic Commerce to be lower cost of trading, faster and better-informed business decisions, and less importance of geography. Other authors mentioned various advantages relevant to Small- and Medium-sized Enterprises such as the "leveling of the playing fields" with the big business [10];location independence $[10,11]$; time independence [11]; the ease of communication and ability to achieve competitive advantages for the businesses [12]. E-commerce permits organizations to access potential customers and suppliers via the web. A number of the most important advantages of e-commerce offers are: expanded marketplaces, potential value reductions, productivity enhancements, customization of product and services, twenty four hour trading and knowledge exchange and management. [13,14]

Table 3. EC Definition [8]

\begin{tabular}{|c|c|}
\hline Perspective & \multicolumn{1}{c|}{ Definition } \\
\hline Communication & $\begin{array}{c}\text { Electronic commerce is the delivery of } \\
\text { information, products/services or Payments } \\
\text { over telephone lines, computer networks or } \\
\text { any other electronic means. }\end{array}$ \\
\hline Business process & $\begin{array}{c}\text { Electronic commerce is the application of } \\
\text { technology towards the automation of } \\
\text { business transactions and work flows. }\end{array}$ \\
\hline Service & $\begin{array}{c}\text { Electronic commerce is a tool that addresses } \\
\text { the desire of firms, consumers, and } \\
\text { management to cut service costs while } \\
\text { improving the quality of goods and } \\
\text { increasing the speed of service delivery. }\end{array}$ \\
\hline Online & $\begin{array}{c}\text { Electronic commerce provides the capacity to } \\
\text { buy and sell products and information on the } \\
\text { Internet, as well as other online services. }\end{array}$ \\
\hline
\end{tabular}

E-commerce is basically changing the economy and therefore the means businesses are conducted these days[15]. It forces companies to search out new ways in which to expand the markets they compete in, to draw in and retain customers by tailoring product and services to their wants and needs, and to restructure their business processes in order to deliver prime quality product and services efficiently and effectively $[16,17]$

Table 4. Top 5 countries with highest number of Internet Users - June 2012[18]

\begin{tabular}{|c|c|c|c|c|}
\hline & Country & $\begin{array}{c}\text { Population, } \\
\text { 2012 Est. }\end{array}$ & $\begin{array}{c}\text { Internet Users } \\
\text { Latest Data }\end{array}$ & $\begin{array}{c}\text { Penetration } \\
\text { (\% of } \\
\text { Population) }\end{array}$ \\
\hline 1 & China & $1,343,239,923$ & $538,000,000$ & $40.1 \%$ \\
\hline 2 & USA & $313,847,465$ & $245,203,319$ & $78.1 \%$ \\
\hline 3 & India & $1,205,073,612$ & $137,000,000$ & $11.4 \%$ \\
\hline 4 & Japan & $127,368,088$ & $101,228,736$ & $79.5 \%$ \\
\hline 5 & Brazil & $193,946,886$ & $88,494,756$ & $45.6 \%$ \\
\hline
\end{tabular}

The amount of trade conducted electronically has grown dramatically since the spread of the Internet. A wide variety of commerce is conducted in this way, spurring and drawing on innovations in electronic funds transfer, supply chain management, Internet marketing, online transaction processing, Electronic Data Interchange (EDI), automated inventory management systems, and automated data collection systems.

Following statistics \& reports indicate that E-commerce is growing in India. Recent findings by internet world stats indicate that India is among the top five countries with highest number of internet users. Table depicts the number of internet users by country ( see table4)

India has relatively few internet users; just 11.4 percent of 
its population is connected to the Web compared to 40.1 percent in China and 78.1 percent in the United States.

Internet Users in the World Distribution by World Regions - 2012 Q2

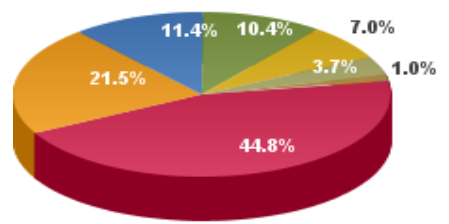

Europe $21.5 \%$

Eorth America $11.4 \%$

Lat Am / Caribb $\mathbf{1 0 . 4 \%}$

Africa $\mathbf{7 . 0} \%$

Middle East $\mathbf{3 . 7} \%$

- Oceania / Australia 1.0\%

Source: Internet World Stats - www.internetworldstats.com/stats.htm Basis: 2,405,518,376 Internet users on June 30,2012

Copyright @ $\bigcirc 2012$, Miniwatts Marketing Group

Graph 2. Internet Users in the World [18]

From above chart it is clear that $44 \%$ of net users are from Asia region.

Summary of findings/ predictions of various research firms about E-commerce in India as follows

Table 5. Summary of findings/ predictions of research firms about E-commerce in India $[19,20,21]$

\begin{tabular}{|c|c|c|}
\hline $\begin{array}{l}\text { Research } \\
\text { Agency }\end{array}$ & $\begin{array}{l}\text { Title of } \\
\text { Report }\end{array}$ & Findings \\
\hline $\begin{array}{l}\text { Internet and } \\
\text { Mobile } \\
\text { Association } \\
\text { of India } \\
\text { (IAMAI)-Ind } \\
\text { ian Market } \\
\text { Research } \\
\text { Bureau } \\
\text { (IMRB) }\end{array}$ & $\begin{array}{c}\text { 'Digital } \\
\text { Commerce' }\end{array}$ & $\begin{array}{c}\text { More than } 121 \text { million active } \\
\text { internet user and INR } 46,520 \text { crores } \\
\text { annual turnover of } \\
\text { e-commerce in India }\end{array}$ \\
\hline $\begin{array}{l}\text { Forrester } \\
\text { Research }\end{array}$ & Predictions & $\begin{array}{c}\text { India to be the fastest growing } \\
\text { E-Commerce Market in Asia-Pacific; } \\
\text { Market Set To Grow to } \$ 8.8 \text { Billion } \\
\text { by } 2016\end{array}$ \\
\hline $\begin{array}{c}\text { Boston } \\
\text { Consulting } \\
\text { Group(BCG) } \\
\end{array}$ & Predictions & $\begin{array}{c}\text { India's Internet economy has been } \\
\text { growing at } 23 \% \\
\text { Y-O-Y }\end{array}$ \\
\hline
\end{tabular}

In 2007; Futurebazaar.com was launched on by Future bazaar India Limited (FBIL) and has emerged as one of the most popular Electronic commerce portals in India. In 2008; Naaptol Electronic commerce Pvt. Ltd. was established. It is the leading comparison based social shopping portal launched in India. The site gets around 10 lakh smart shoppers a month which is increasing with each passing day.

In 2009; Indiatimes is the Internet subsidiary of The Times of India Group and is one of the most popular web portals in India. Indiatimes Shopping, the e-commerce portal of Indiatimes is India's largest Electronic commerce platform and features over 7 Million products from different categories including from books, music, movies, electronics, apparel, accessories etc. Easy access to various brands and models, free home delivery, discounts and coupons turned many of the web users to web consumers in India. Improved payment methods such as cash on delivery, net-banking facility, etc. have spurred the growth of online retail transactions. Some online retailers like Flipkart, eBay, Indian marketplace etc. are fairly popular in India.

With all these success stories, Indian e-commerce industry is expected to grow manifold in the near future. However, the continuous growth of the e-commerce depends on creating increased awareness among the people \& in enterprises about the benefits of online services along with the assurance of secured transactions and improved data security.

\section{Review of Literature}

\subsection{Theoretical Framework}

\subsubsection{Technology-Organization-Environment Framework}

The process by which a firm adopts and implements technological innovations is influenced by the technological context, the organizational context, and the environmental context. The technological context includes the internal and external technologies that are relevant to the firm. Technologies may include both equipment as well as processes. The organizational context refers to the characteristics and resources of the firm, including the firm's size, degree of centralization, degree of formalization, managerial structure, human resources, amount of slack resources, and linkages among employees. The environmental context includes the size and structure of the industry, the firm's competitors, the macroeconomic context, and the regulatory environment. 


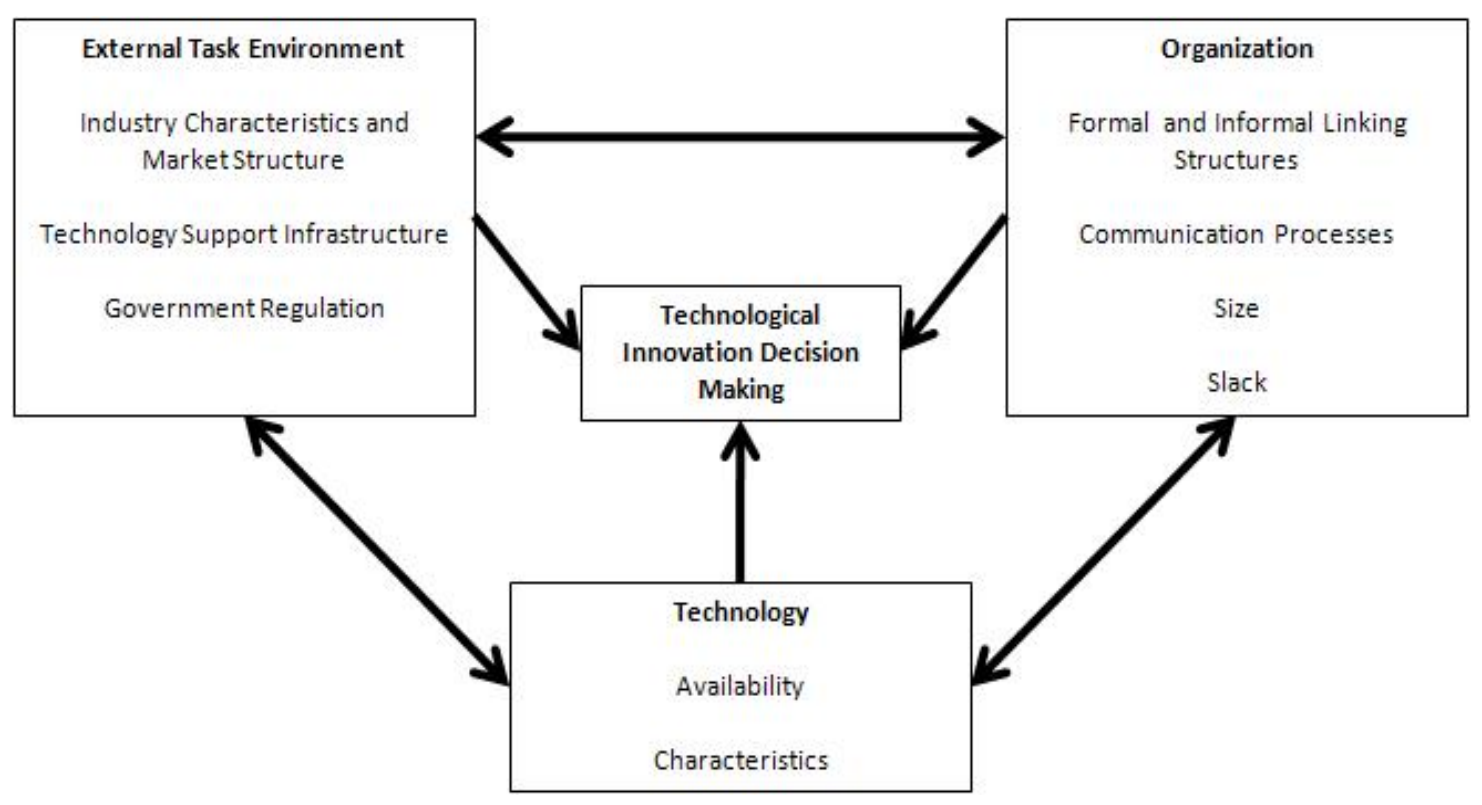

Figure 1. TOE Framework [22]

\subsubsection{Innovation Diffusion Theory}

The innovation diffusion theory or diffusion of innovation (DOI) focuses on the perceived characteristics of innovations, postulating the five determinations of technology adoption, i.e., relative advantage, complexity, compatibility, trialability and observability.[23] This theory has been used in previous research to explain IT adoption in general [24] and e-commerce adoption in particular [25]. Premkumar's [26] study showed that relative advantage, compatibility and complexity are consistently related to innovation adoption.

\section{2 Grouping of variables based on TOE Framework}

Electronic Commerce has technical components, similar to other IT innovations, but Electronic Commerce also has inter-organizational elements which distinguish it from other types of innovations. All previous studies variables are grouped in Technology-Organization-Environment Framework (TOE).

\subsubsection{Technological Context}

The technological context represents the pool of technologies available to a firm, which can be both the technologies available on the market and the firms' current equipment. The decision to adopt a technology depends not only on what is available on the market, but also on how such technologies fit with the technologies that a firm already possesses.

\subsubsection{Relative Advantage}

Relative advantage is the degree to which an innovation is seen as superior to existing practice [23]. In the literature, Relative Advantages has been identified as an important factor effecting implementation of e-commerce in SMEs.
Relative Advantages are the benefits that are offered by e-commerce in comparison to the traditional way of doing business. Relative Advantages of e-commerce include increased sales, improved communication with customers, suppliers and employees and easier order tracking [27]. Importance of perceived benefits in effecting e-commerce adoption has been emphasized in the literature by a large number of researchers [28-31]. It has positive association with E-Commerce implementation.

\subsubsection{Compatibility}

Compatibility refers to the degree to which an innovation is perceived as consistent with the existing socio-cultural values, past experiences, and previously introduced ideas and need of adopters [23]. In the context of this study Compatibility refers to the degree to which e-commerce applications are compatible with the current practices of the company such as value chain relations and firm's processes. In the literature, compatibility is observed to be affecting the adoption of innovation [32], the rate of adoption of innovation [23] and adoption of e-commerce technologies [33] positively. Level of compatibility and adoption of the innovation are positively related [23,32]. In addition, compatibility with current business practice is a significant factor effecting adoption of e-commerce technologies $[33,34]$.

\subsubsection{Complexity}

Complexity is the degree to which an innovation is perceived as relatively difficult to understand and use [23]. Complexity has a negative association with E-Commerce implementation [35-40].

\subsubsection{Organizational Context}

The organizational context represents the internal factors to an organization that influence an innovation adoption. 


\subsubsection{Financial Commitment}

Cost has been a significant factor effecting operations of firms due to the high investment requirements in hardware, software and employee training. Adequacy of financial resources enables firms to make necessary investments for developing superior e-business functionalities and e-business value. Zhu et al. [41] indicated financial resources as significant facilitators of e-business value creation in their empirical study of analyzing e-business value drivers. In this study, financial resources provided additional evidence to literature by showing a positive effect on e-commerce performance. Financial resources have been observed as a significant factor effecting e-commerce adoption and usage of SMEs by Scupola [42] and Zhu et al. [43].

\subsubsection{Top management support}

Previous studies indicate that top management support has been an important factor in IS/IT adoption [44] and it is a significant factor in differentiating adopters and non-adopters of e-commerce in small businesses [45]. Top management support is also a significant critical success factor for Business to Business Electronic Commerce (B2BEC) adoption [46]. Furthermore, Kutlu and Ozturan [47] indicated that business owners and managers with positive attitude towards IT tend to be more successful in adoption and implementation of new technology with the evidence from SMEs. Previous studies indicate that top management support, has a critical role in developing IS/IT competencies, in the IS/IT success [44] and in e-commerce adoption decision [45, 48]

\subsubsection{Profile of SMEs}

Organizational size which indicates the level of operational resources of the company has been regarded as a significant factor effecting performance of companies [49]. It is indicated as a factor effecting organizational capability to adopt innovation positively by researchers studying organizational innovation [50]. Similarly, in the context of e-commerce, organizational size has been found to be a significant factor effecting e-commerce adoption [12,51-54].

\subsubsection{Profile of owner/IT head}

IT skills and experience of its employees are key knowledge assets of a company [55]. When these assets are insufficient an organization has to arrange training programs for creating new IT skills or new employees with IT skills and experience are employed. Even with new employees having IT skills and experience time is needed to gain organizational experience which is unique to each and every organization due to its distinctive characteristics such as organizational culture, organizational climate, interpersonal relations, rights, privileges and norms.

Lack of internal expertise can be a factor delaying the innovation [56]. In the literature, previous IT experience has been observed to be an important factor effecting success of the IT adoption. Findings from Palvia and Palvia [57] and Sparling et al. [32] indicate that age and experience of owner are very important factors in the success of IT adoption. When a company owner who actually has great influential power on top management explains the role of IT in achieving his/her vision, attitudes of managers will be affected and the level of priority of IT related issues in all decisions will increase.

\subsubsection{Environment context}

The environment is the arena in which an organization conducts its business and in the specific context of e-commerce adoption in SMEs it includes competitive pressures and pressure from trading partners.

\subsubsection{Trading Partner Pressure}

Competitors, suppliers and customers may force small businesses to engage in e-commerce activities [42].External pressure from competitors, government and industry are of great importance in the adoption decision [30], adoption and implementation [42] of e-commerce in SMEs and it is an important influencing factor in corporate website adoption [31]. According to Fink and Kazakoff [58], SMEs are usually characterized by a high level of environmental uncertainty such as fluctuations in interest rates, reliability of supply, competition, etc. With the relevant point, the use of IT and Electronic Commerce is often imposed on SMEs by major customers or suppliers. Such pressure from trading partners plays a critical role in previous studies of IT and Electronic Commerce adoption by small firms $[12,31,59,60]$.

\subsubsection{Competitive pressure}

Existence of intense competition is a motivating factor for companies in order to differentiate and stay at least one step ahead of their competitors. As the number of competitors adopting innovation increases, small firms have more tendencies to adopt the innovation for sustaining their competitive position [32]. A positive association between the competition intensity and e-commerce adoption decisions $[25,34]$ has been identified in the literature. Competition has been found to be a motivator factor for Small and Medium Enterprises to adopt e-commerce and IS innovations[61].

\subsubsection{Information intensity:}

Information intensity refers to dependency of firm on reliable, relevant $\&$ accurate information [62]. Information intensity had positive association with E-Commerce implementation [39,40,63-66].

\subsubsection{4 .Government Support}

The impact of government policies and initiatives has been shown to have direct and indirect stimulation to the supply of information which produces faster technology diffusion. In addition, as computers and telecommunication technology has progressed, many governments are now refocusing their attention from traditional "brick and mortar" infrastructure development to electronic communications 
and transport projects. Other examples of governmental efforts to establish a national information infrastructure (NII) in U.S. and Singapore [67,68] have shown that both governments provide a legitimate and positive leadership role in developing the information infrastructure in its effort to digitize its economy. Government Support had positive association with E-Commerce implementation. $[36,37,39,69,70]$.

\section{The Necessity \& Significance of the Study}

Large organizations have enough resources to adopt E-commerce; while on the other hand MSMEs have limited financial and human resources to implement E-commerce. MSMEs could be seen as being no different from their larger corporate cousins in one key aspect; namely, to survive and prosper in competitive business areas. Organizations these days are faced with large globalization, demanding customers with rapidly changing needs, shrinking response time, shrinking product lifecycles and demanding staff.

\subsection{Research Gaps in Literature on Use of E-commerce in SME}

- Only handful of E-Commerce studies exists in Indian context \& most of them are conceptual in nature, and mostly based on secondary data sources [71].

- $\quad$ The adoption of web-enabled transaction processing by small business has not been as Widespread as would are expected [72].

- $\quad$ There are very few studies about ICT adoption in developing countries[9].

- It has been observed and verified in many studies that SMEs have been actively looking for suitable solution and methods of adopting and integrating Electronic Commerce into their business process. $[11,73,74]$.

Although there is a growing body of literature on B2C context of Electronic Commerce, but there is little empirical research on B2B context of Electronic Commerce particularly in India.

\subsection{Government Efforts/Concerns about E-commerce in Indian MSMEs}

- Financial support to engineering/technical institutes for undertaking research for technological up gradation in MSMEs. To encourage such research, $150 \%$ deduction is allowed for contribution made towards funding of R\&D work in engineering technical institutes under section 10 (21) of Income Tax Act. [75].

- The adoption of ICT (Information and
Communication Technology) for MSMEs should be encouraged on highest priority to enable SMEs to compete in global market. $12^{\text {th }}$ five year plan has separate component \& allocation of funds for Implementation of Information and Communication Technology(ICT) in SMEs [75].

- Technology will be the foremost factor for enhancing the global competitiveness of Indian MSME Sector. Without infusion of appropriate technology, survival in the global market place would be a question mark for a large majority of micro \& small enterprises and even the medium enterprises [75].

- The National Manufacturing Competitiveness Program (NMCP) has separate component \& allocation of funds for Implementation of Information and Communication Technology (ICT) in Manufacturing sector MSMEs [5].

- The Prime Minister's Task Force on MSMEs has identified low technology, generally used by the MSME sector, as a major cause for poor competitiveness of the sector [76].

The successful implementation of e-commerce by MSMEs would affect the entire India's economy. There is growing evidence that MSMEs is falling behind in the race for sustainable and valuable use of online business, a large percentage of them do not use the internet daily in their business operations.

With the increasing global economic integration, international market has become much wider than the domestic market for MSMEs. Over the years, the share of MSMEs in total manufacturing export has risen to a healthy level of over 40 percent. However, this rosy figure comes with a caution that hardly one percent of MSMEs are exporting units. This calls for widening and deepening of international markets by MSMEs. Globalization and WTO norms make profound impact on the existence as well as market of MSMEs. On the other side, there is a rising domestic market due to rising income. MSMEs need to tap these potential markets by way of aggressive marketing, improved technology and better competitiveness. It is important to provide an additional impetus to the MSME sector as it is likely to have a multiplier impact on Indian economic growth in this decade.

\section{Proposed Conceptual Research Framework}

Using theoretical foundations from established information systems implementation research, Innovation Diffusion theories \& TOE framework, Electronic Commerce and small business literature, this research seeks to explain Electronic Commerce implementation by examining factors that may be associated with the implementation of Electronic Commerce within organizations and between its business partners. List of research variables are as follows ( table 6) 
Table 6. List of Research Variables

\begin{tabular}{|c|c|}
\hline Construct & Variables \\
\hline \multirow{3}{*}{$\begin{array}{l}\text { Technological } \\
\text { context }\end{array}$} & 1. Relative advantage \\
\hline & Compatibility \\
\hline & 3. Complexity \\
\hline \multirow{4}{*}{$\begin{array}{c}\text { 2. Organizational } \\
\text { context }\end{array}$} & 1. Financial commitment \\
\hline & 2. Top management support \\
\hline & 3. Profile of MSME \\
\hline & 4. Profile of owner/IT head \\
\hline \multirow{4}{*}{$\begin{array}{l}\text { 3. Environmental } \\
\text { context }\end{array}$} & 1. Trading partner pressure \\
\hline & Competitive pressure \\
\hline & 3. Information intensity \\
\hline & 4. Government support \\
\hline
\end{tabular}

The relationships of these factors with the implementation of Electronic Commerce in MSMEs are shown in following Figure.

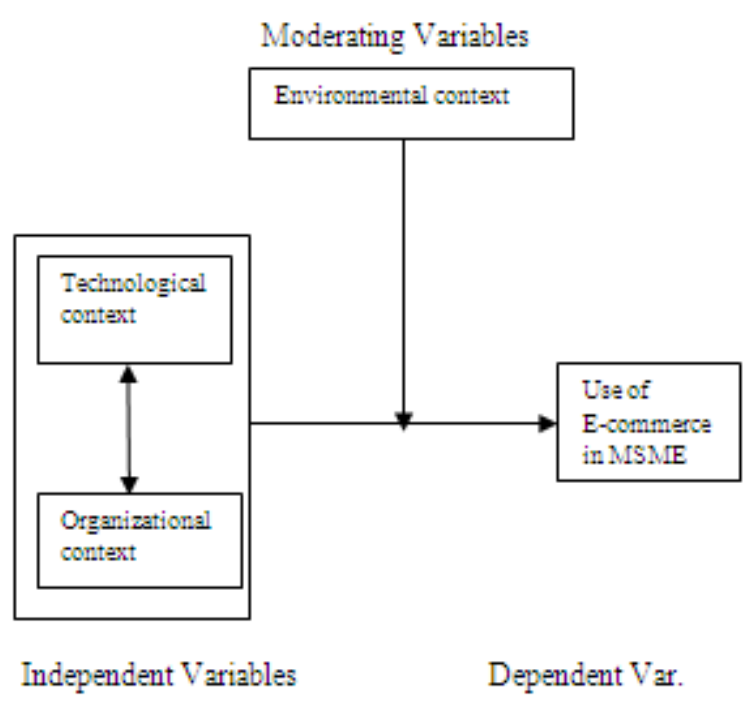

Figure 2. Conceptual research model

\section{Conclusion}

The proposed research will contribute to filling the gaps left in different previous studies of India. After completion of the research, we hope that SMEs will increase their abilities to compete and get into a stable situation, because the research will introduce appropriate strategies that SMEs can follow to sustain growth with the help of E-commerce. This research has implications for policy makers, ICT managers and owners of MSMEs.

\section{Acknowledgments}

I have been thankful for my thesis advisory committee (TAC) for guidance; Dr. Bala Krishnamoorthy, Dr. Gita Kumta \& Dr. Hema Date.

\section{REFERENCES}

[1] Akkeren J. \& Cavaye, A.L.M. , "Factors Affecting Entry-Level Internet Technology adoption by Small Business in Australia: An Empirical Study”, proceedings of the 10th Australasian Conference on Information Systems, Wellington, New Zealand, 1-3 December 1999.

[2] Gilaninia, Seyed Danesh, S.Y; Amiri, M ;Mousavian, S.J., "Effective Factors on Adoption of E-Commerce in SME Cooperative", Interdisciplinary journal of contemporary research in Business, Vol. No. 6, pp13-21, 2011.

[3] Micro, Small and Medium Enterprises Development (MSMED) Act, 2006 of Government of India (GOI) available at www.dcmsme.gov.in/MSMED2006.pdf

[4] Government of India, Ministry of MSME Annual Reports, 2011-12 \& 2012-13.Available online at http://msme.gov.in/

[5] Government of India, Department of Industrial Policy and Promotion of Ministry of Commerce and Industry, "National Manufacturing Policy 2011", Available online at http://dipp.nic.in/

[6] Government of India, Report of Planning commission's working group on, "Micro small medium enterprises (MSMEs) Growth"; for the 12th five year plan (2012-17) New Delhi: Planning commission's Office. Available online at http://msme.gov.in/

[7] Agarwal, S.P, Report on "Strategy for Enhancing Competitiveness of SMEs Based on Technology Capacity Building", UN Economic And Social Commission For Asia And Pacific (ESCAP), Bangkok,2005.

[8] Kalakota, R. and Whinston, A., "Electronic Commerce: A Manager's Guide", Addison- Wesley Longman,1997.

[9] Schmid, B., K. Stanoevska-Slabeva, and V. Tschammer, "Towards the E-Society: E-Commerce, E-Business, E-Government" Zurich, Switzerland, 2001.

[10] Longenecker, J., Moore, C. and Petty, J., "Small Business management: An Entrepreneurial Emphasis", SWC Publishing, 10th Edition,1997.

[11] Purao, S. and Campbell, S. , "Critical concerns for small business electronic commerce: some reflections based on interviews of small business owners", AIS Conference proceedings, Baltimore, Maryland,1998.

[12] Iacovou, C., Benbasat, I. and Dexter, A. ,"Electronic data interchange and small organisations: adoption and impact of technology”, MIS Quarterly, 19(4), pp.465- 485,1995.

[13] McIvor, R. and Humphreys, P. , "The Implications of Electronic B2B Intermediaries for the Buyer-Supplier Interface", International Journal of Operations \& Production 
Management, Vol. 24, No. 3, pp. 241-269, 2004.

[14] Raisinghani, M. S., Melemez, T., Zhou, L., Paslowski, C., Kikvidze, I., Taha, S., and Simons, K. ,"E-Business Models in B2B: Process Based Categorization and Analysis of B2B Models, International Journal of E-Business Research, Vol.1, No. 1, pp. 16-36, 2005.

[15] Barua, Anitesh, Prabhudev Konana, Andrew B. Whinston, and Yin Fang (2001),"Driving E- Business Excellence", MIT Sloan Management Review, 43 (1), 36-44, 2001.

[16] Chan, S., and Davis, T., "Partnering on extranets for strategic advantage", Information Systems Management, Vol. 17, No 1, pp. 58-64, 2000.

[17] Shin, N. (2001), "Strategies for competitive advantage in electronic commerce", Journal of Electronic Commerce Research, Vol. 2, No.4, pp. 34-41.

[18] Online available at http://www.internetworldstats.com

[19] Online available at www.iamai.in \& www.imrbint.com

[20] Online available at www.forrester.com/

[21] Online available at www.bcg.com

[22] Tornatzky, L.G. and Fleischer, M., "The Processes of Technological Innovation”, Lexington Books, Lexington, 1990.

[23] Rogers, E.M. , "Diffusion of Innovations", 4th ed., The Free Press, New York, NY,1995.

[24] Kaynak, E., E. Tatoglu and V. Kula, "An analysis of the factors affecting the adoption of electronic commerce by SMEs: Evidence from an emerging market", International Market Review, 22: 623-640, 2005.

[25] Wongpinunwatana, N. and C. Lertwongsatien, "E-commerce adoption in Thailand: An empirical study of Small and Medium Enterprises (SMEs)", Journal of Global Information Technology Management, 6:67-82,2003.

[26] Premkumar, G. , "A meta-analysis of research on information technology implementation in small business", Journal of Organizational Computing and Electronic Commerce, Vol. 13, No. 2, pp. 91-121,2003.

[27] Baldwin, A., A. Lymer and R. Johnson,"Business Impacts of the Internet for Small and Medium-Sized Enterprises In: E-Commerce and V-Business: Business Models for Global success, Hunt, B. and S. Barnes (Eds.), Butterworth-Heinemann, New York, pp: 103-120,2000.

[28] Mehrtens, J., P.B. Cragg and A.M. Mills, "A model of Internet adoption by SMEs", Information Management, 39: 165-176, 2001.

[29] Kutlu, B. and M. Ozturan, "The usage and adoption of IT among SMEs in Turkey: An exploratory and longitudinal study", Journal of Information Technology Management, 19: 12-24, 2008.

[30] Grandon, E. and J.M. Pearson, "E-commerce adoption: Perceptions of managers/owners of small and medium sized firms in Chile", Communication Association of Information System., 13: 81-102, 2004.

[31] Beatty, R., " An empirical investigation into the salient factors used by organisations in the adoption of Web site technology", Mississippi State University, DBA,1998.

[32] Sparling, L., M. Toleman and A. Cater-Steel, "SME adoption of E-commerce in the central Okanagan region of Canada", proceedings of the 18th Australasian Conference on Information Systems, December 5-7, 2007.

[33] Kendall, J.D., L.L. Tung, K.H. Chua, C.H.D. Ng and S.M. Tan, " Receptivity of Singapore's SMEs to electronic commerce adoption", Journal of Strategic Information System, 10: 223-242, 2001.

[34] Al-Qirim, N., "The adoption of e-commerce communications and applications technologies in small businesses in New Zealand", Electronic Commerce Research Applications, 6: 462-473, 2007.

[35] Kuan, K.K.Y. and Chau, P.Y.K., "A perception-based model for EDI adoption in small businesses using a technology-organization-environment framework", Information \& Management, Vol. 38, No. 8, pp 507-521, 2001.

[36] Zhu, K., Dong, S.T., Xu, S.X. and Kraemer, K.L., "Innovation diffusion in global contexts: Determinants of post-adoption digital transformation of European companies", European Journal of Information Systems, Vol. 15, No. 6, pp 601-616,2006.

[37] Soares-Aguiar, A. and Palma-Dos-Reis, A., "Why do firms adopt e-procurement systems? Using logistic regression to empirically test a conceptual model", IEEE Transactions on Engineering Management, Vol. 55, No. 1, pp 120-133,2008.

[38] Liu, M., "Determinants of e-commerce development: An empirical study by firms in Shaanxi, China", 4th International Conference on Wireless Communications, Networking and Mobile Computing, Dalian, China, October, Vols 1-31, pp 9177-9180,2008.

[39] Chong, A.Y.L. and Ooi, K.B., "Success in electronic commerce implementation: A cross-country study of small and medium-sized enterprises", Journal Entrepreneurship Information Management, 21: 468-492, 2008.

[40] Wang, Y.M., Wang, Y.S. and Yang, Y.F. , "Understanding the determinants of RFID adoption in the manufacturing industry", Technological Forecasting and Social Change, Vol. 77, pp. 803-815,2010.

[41] Zhu, K., Xu S. and J. Dedrick, "Assessing drivers of e-business value: Results of a cross-country study", Proceedings of the 24th International Conference on Information Systems, December 14-17, 2003, Seattle, Washington, USA,2003.

[42] Scupola, A., (2003), "The Adoption of Internet Commerce by SMEs in the South of Italy: An Environmental, Technological and Organizational Perspective," Journal of Global Information Technology Management, Vol. 6, No.1, pp. 51-71,2003.

[43] Zhu, K., K.L. Kraemer and Xu S., (2002), “A cross-country study of electronic business adoption using the technology-organization-environment framework", Proceedings of the 23th International Conference on Information Systems, December 15-18, 2002, Barcelona, Spain, pp: 337-348.

[44] Caldeira, M.M. and J.M. Ward, "Understanding the successful adoption and use of IS/IT in SMEs: An 
explanation from Portuguese manufacturing industries", Information System Journal., 12: 121-152, 2002.

[45] Mirchandani and Motwani , "Understanding Small Business Electronic Commerce Adoption: An Empirical Analysis", Journal of Computer Information Systems, Spring, 41:70-73,2001.

[46] Tsao, H.Y. and H.C.L. Koong, "An investigation of critical success factors in the adoption of B2B-EC by Taiwanese companies", proceedings of the BAI 2004 International Workshop on Business and Information, March 26, 2004.

[47] Kutlu, B. and M. Ozturan, "The usage and adoption of IT among SMEs in Turkey: An exploratory and longitudinal study", Journal of Information Technology Management, 19: $12-24,2008$

[48] Nasco, S.A., E.G. Toledo and P.P. Mykytyn Jr, "Predicting electronic commerce adoption in Chilean SMEs" Journal of Business Research, 61: 697-705,2008.

[49] Lun, Y.H.V. and M.A. Quaddus, "Firm size and performance: A study on the use of electronic commerce by container transport operators in Hong Kong”, Expert System Application, 38: 7227-7234, 2011.

[50] Lee, G. and W. Xia, (2006), "Organizational size and IT innovation adoption: A Meta-analysis", Information Management, 43: 975-985, 2006.

[51] Zhu, K. and K.L. Kraemer, "E-commerce metrics for Net-enhanced organizations: Assessing the value of e-commerce to firm performance in the manufacturing sector", Information System Research, 13: 275-295,2002.

[52] Ling, C.Y., (2001), "Model of factors influences on electronic commerce adoption and diffusion in small and medium sized enterprises", School of Information Systems, Curtin University of Technology, Australia,2001.

[53] Nilakanta, S. and Scamell, R. , "The effect of information sources and communication channels on the diffusion of innovation in a data base development environment", Management Science, 36(1), pp.24-40, 1990.

[54] Igbaria, M., Zinatelli, N. and Cragg, P., "Personal computing acceptance factors in small firms: A structural equation", MIS Quarterly, 1997.

[55] Bharadwaj, A.S., "A resource-based perspective on information technology and firm performance: An empirical investigation", Management Information System, 24: 169-196,2000.

[56] Thong, J.Y.L. ,"An integrated model of information systems adoption in small business", Journal of Management Information Systems, Vol.15, Issue 4, pp. 187-214,1999.

[57] Palvia, P.C. and S.C. Palvia, (1999), "An examination of the IT satisfaction of small business users", Information Management, 35: 127-137.

[58] Fink, D. and Kazakoff, K. (1997) "Getting IT right", Australian Accountant, 67(10),pp.50-52,1997.

[59] Swatman, P. ,"Electronic Data Interchange: Organisational Opportunity, Not Technical Problem", in Databases in the 1990's, Srinivasan, B. and Zeleznikow, J. (eds.), World Scientific Press, Singapore, pp.354-374,1991.
[60] Webster, J., "EDI in a UK Automobile Manufacture: Creating Systems, Forming Linkages, Driving Changes", the Seventh Electronic Data Interchange Conference proceedings, Bled, Solvenia, Yugoslavia,1994.

[61] Zhu, K., Xu S. and J. Dedrick, "Assessing drivers of e-business value: Results of a cross-country study", Proceedings of the 24th International Conference on Information Systems, , Seattle, Washington, USA, December 14-17, 2003.

[62] Thong, J.Y.L. and Yap, C.S., "CEO characteristics, organizational characteristics and information technology adoption in small businesses", Omega, Vol. 23 No. 4, pp. 429-42,1995.

[63] Zhu, K. and Kraemer, K.L., (2005), "Post-adoption variations in usage and value of e-business by organizations: Cross-country evidence from the retail industry", Information Systems Research, Vol. 16, No. 1, pp 61-84,2005.

[64] Teo, T.S.H., Ranganathan, C. and Dhaliwal, J. , "Key dimensions of inhibitors for the deployment of web-based business-to-business electronic commerce", IEEE Transactions on Engineering Management, Vol. 53, No. 3, pp 395-411, 2006.

[65] Liu, M.,"Determinants of e-commerce development: An empirical study by firms in Shaanxi, China", 4th International Conference on Wireless Communications, Networking and Mobile Computing, Dalian, China, October, Vols 1-31, pp 9177-9180, 2008.

[66] Morteza Ghobakhloo, Tang Sai Hong, Mohammad Sadegh Sabouri and Norzima Zulkifli, "Strategies for Successful Information Technology Adoption in Small and Medium-sized Enterprises", Information, Vol. 3,pp 36-67,2012.

[67] Kettinger, J. "National infrastructure diffusion and the U.S. information super highway", Information and Management, Amsterdam, Dec., 27(6), pp.357-369, 1994.

[68] Tan, M., "Creating the digital economy: perspectives from Singapore", Electronic Commerce in the Information Society, proceedings from the 11th International Electronic Commerce Conference, Bled, Slovenia, June 8-10,1998.

[69] Lin, H.F. and Lin, S.M. , "Determinants of e-business diffusion: A test of the technology diffusion perspective", Technovation, Vol. 28, No. 3, pp 135-145,2008.

[70] Li, Y.H. , "An empirical investigation on the determinants of e-procurement adoption in chinese manufacturing enterprises", International Conference on Management Science \& Engineering (15th), California, USA, Vols I and II, Conference Proceedings, pp 32-37,2008.

[71] Sridhar Vaithianathan, "A review of e-commerce literature on India and research agenda for the future", Journal of Electronic commerce Research, Springer USA, Vol.10,Issue 1,pp 83-97,2010

[72] Stockdale R. \& Standing C., "A classification model to support SME e-commerce adoption initiatives" , Journal of Small Business and Enterprise Development, Vol.13, Iss.3,pg.381,2006.

[73] Cragg, P. and King, M. , "Small-firm computing: motivators and inhibitors", MIS Quaterly, 17(1), pp.47-60,1993. 
[74] Dos Santos, B. and Peffers, K., "Competitor and vendor influence on the adoption of innovative applications of electronic commerce", Information \& Management, 34, pp.175-184,1998.

[75] Government of India, Report of Planning commission's working group on, "Micro small medium enterprises (MSMEs) Growth"; for the 12th five year plan (2012-17)
New Delhi: Planning commission's Office, 2012. Available online at http://msme.gov.in/

[76] Government of India, Report of the Prime Minister's Task Force on "Micro, Small and Medium Enterprises (MSMEs)", New Delhi: Prime Minister's Office (Chairman of the Task Force: T.K.A. Nair),2010. Available online at http://msme.gov.in/ 